\title{
CONSIDER A CYLINDRICAL CAVE: A PHYSICIST'S VIEW OF CAVE AND KARST SCIENCE
}

\section{VZEMIMO VALJASTO JAMO: POGLED FIZIKA NA ZNANOST O JAMAH IN KRASU}

\author{
Matthew D. COVINGTON ${ }^{1} \&$ Matija PERNE 2
}

\begin{abstract}
UDC 551.44:53

Matthew D. Covington \& Matija Perne: Consider a cylindrical cave: A physicist's view of cave and karst science

We review the current understanding of the physics of caves and karst. Our review focuses on research that has used simple physically based models to improve understanding of processes that occur in karst. The topics we cover include cave atmosphere dynamics, transport within karst conduits, and models of speleogenesis and related processes. We highlight recent advances in these subjects and attempt to identify promising areas for future work. In our judgment, many of the most intriguing open questions relate to the interactions between these three groups of processes.
\end{abstract}

Keywords: Karst, speleology, physics, mathematical modeling, cave meteorology, hydrology, speleogenesis.
Izvleček UDK 551.44:53

Matthew D. Covington \& Matija Perne: Vzemimo valjasto jamo: pogled fizika na znanost o jamah in krasu

$\mathrm{V}$ članku pregledava trenutno poznavanje fizike jam in krasa. Pri tem se osredotočava na raziskave, ki so razumevanje kraških procesov poglobile $\mathrm{z}$ uporabo preprostih modelov na osnovi fizike. Obravnavava vedenje jamskega ozračja, transport v kraških kanalih in modele nastanka jam ter povezanih procesov. Izpostavljava sodobna dognanja na teh področjih in iščeva obetavne teme za nadaljnje raziskave. Po najinem mnenju so mnoga med bolj privlačnimi odprtimi vprašanji povezana $\mathrm{z}$ medsebojnim vplivom med obravnavanimi tremi skupinami procesov.

Ključne besede: Kras, speleologija, fizika metematično modeliranje, jamska meteorologija, speleogeneza.

\section{INTRODUCTION}

When a colleague excitedly showed Eugene Wigner the result of a complex quantum mechanical calculation produced by a computer, Wigner's storied reply was, "It is nice to know that the computer understands the problem, but I would like to understand it too (Heller \& Tomsovic 1993)." This reply reflects a general attitude in theoretical physics, that one has not really understood something until one has an analytical mathematical model for it. While computers play an increasingly dominant role in quantitative science, and we are more and more awash with data, analytical models retain an important function. Often the results of computer simulations can be difficult to generalize beyond the particular cases run. Analytical models can provide a powerful tool for understanding the results of these simulations and illuminating relevant general principles. They can play a very similar role in data analysis. Within the field of physics, there is arguably a bias toward the analytical, the simple, the elegant. However, it is certainly a bias that has served physics well (Wigner 1960), along with many other fields.

\footnotetext{
${ }^{1}$ University of Arkansas Department of Geosciences Fayetteville, Arkansas, USA, e-mail: mcoving@uark.edu

${ }^{2}$ University of Arkansas Department of Geosciences Fayetteville, Arkansas, USA, Jožef Stefan Institute, Department of Systems and Control Ljubljana, Slovenia
}

Received/Prejeto: 02.03.2015 
It is our task in this article to review the physics of caves. Given that basic physics underpins our understanding of a wide variety of processes that occur in caves and karst, we must choose a narrower lens through which to view the topic. The lens that we have chosen is that of the simple physics-based model. There is an increasingly well-worn path into karst science that has been trodden by physicists. Most of these scientists have entered karst science as physicist cavers, whose passion and curiosity about the underground world inspired their scientific contributions to karst studies (e.g. the interview of Wolfgang Dreybrodt in Lučić 2011). The work done by this group of physicists has often focused on simple and general models. This work has employed analytical solutions, dimensional analysis, and simple numerical models to enable understanding of more complex experimental and observational work. Therefore, in choosing to focus on simple models, we have also chosen to focus on the type of work that physicists have most often undertaken when they have delved into the realm of karst. We also focus more heavily on recent contributions, in hopes of illuminating promising areas for future work.

\section{CAVE CLIMATE AND METEOROLOGY}

The study of cave atmospheres has frequently attracted researchers with a background in physics. Perhaps this results from the ease with which the laws of physics can be applied to the problem, or perhaps from the curiosity of cavers who are always following the wind. The two most complete works on cave atmospheres have been written from a physics perspective (Badino 1995; Lismonde 2002), and a prior review of cave physics devoted about half of its space to this topic (Wigley \& Brown 1976). Cave atmospheres are known for their constancy in comparison to the surface atmosphere. However, cave atmospheres are not truly constant, and it is their variability in space and time that poses many of the most interesting questions and most relevant unknowns.

The physics of cave atmospheres was recently reviewed by Badino (2010), who divides the field into "cave climatology," the study of the average cave atmospheric conditions that vary slowly in time, and "cave meteorol- ogy," the study of how the cave fluctuates around this average condition over relatively short timescales. We adopt this division here, as it seems an apt analogy to the traditional fields of climatology and meteorology. However, there is a difference in scale and degree. While a meteorologist often studies relatively dramatic phenomena, a cave meteorologist may study diurnal or seasonal variations on the order of $0.1{ }^{\circ} \mathrm{C}$ and humidity variations of a few percent. Understanding cave atmospheres, their variability, and the factors that control them is increasingly important as we seek to interpret paleoclimate records from caves (Fairchild et al. 2006). The dynamics of cave atmospheres also has important implications for cave ecosystems (e.g. Culver 2005; Tobin et al. 2013), the protection of caves from anthropogenic impacts (e.g. Cigna 1993; Hoyos et al. 1998), and the formation and evolution of caves over time (e.g. Dreybrodt et al. 2005b; Covington et al. 2013).
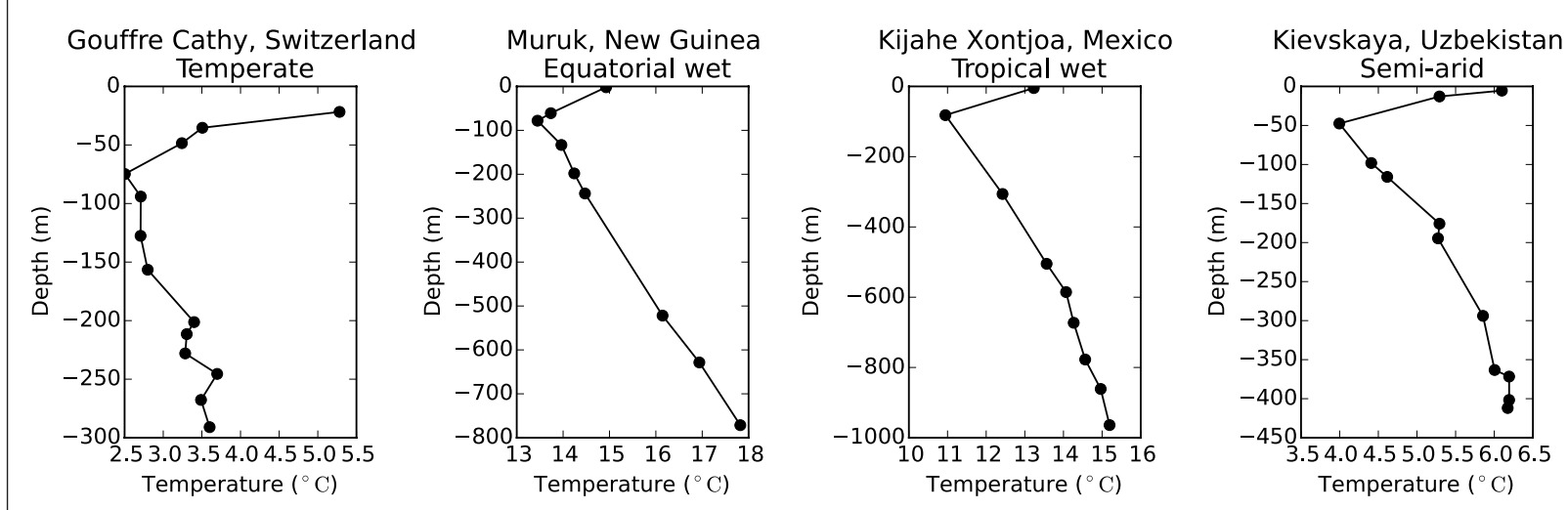

Fig. 1: Temperature profiles with depth in deep cave systems in different climatic settings. Reproduced using data from Luetscher \& Jeannin (2004). 


\section{LARGE SCALE THERMAL DYNAMICS OF KARST AQUIFERS}

The average local temperature on the surface exerts a first-order control on cave temperature. Therefore cave temperature is strongly dependent on both altitude and latitude. More specifically, the temperature is primarily controlled by the average temperature of the fluids that flow through the aquifer, both air and water (Luetscher \& Jeannin 2004; Badino 2010). Karst aquifers receive geothermal flux from below, and a heat flux from above that is driven by surface temperature. However, for the unsaturated zone of unconfined karst aquifers, the geothermal and surface heat flow rates are typically dwarfed by the heat capacity rate of the fluids that cross the aquifer, such that the temperature inside the aquifer is approximately equilibrated to the average temperature at the surface at the same altitude (Bogli 1980; Luetscher \& Jeannin 2004; Badino 2005). Karst can be considered an end-member case among aquifers, where advective heat transport dominates over conductive processes. This can be expressed quantitatively by stating that Péclet numbers for heat transport are large within karst systems (Domenico \& Palciauskas 1973), where the Péclet Number is a ratio of the advective and conductive heat transport rates. Consequently, in deep unsaturated zones, once below the shallow surface-influenced zone, karst aquifers display a systematic increase in temperature with depth that is typically much less than the normal geothermal gradient of approximately $2.5^{\circ} \mathrm{C} / 100$ $\mathrm{m}$. Observed thermal gradients in deep caves (Fig. 1) are between the values of the energy dissipation rate of falling water $\left(0.234^{\circ} \mathrm{C} / 100 \mathrm{~m}\right)$, and the adiabatic lapse rate of moist air $\left(0.5^{\circ} \mathrm{C} / 100 \mathrm{~m}\right)$ (Luetscher \& Jeannin 2004).

Luetscher \& Jeannin (2004) argue from estimates of air flux in two caves (Hölloch and La Diau) that the energy flux due to air circulation is 2 to 20 times larger than the energy flux due to water. They cite as further evidence that many of the observed caves display thermal gradients close to the adiabatic lapse rate of moist air. However, Badino (2010) asserts that these authors overestimate typical air flux and concludes that water is the dominant factor in most settings. In either case, observed temperature gradients typically lie between those expected by the dominance of air and water. Climate also appears to be an important factor in determining temperature profiles, with caves in wetter climates displaying lower gradients (i.e. more water dominated) than in drier climates (Fig. 1). Many of the temperature profiles also display reduced gradients within the deeper portion of the cave, where the influence of air is reduced. The debate on the relative importance of water and air in determining thermal profiles highlights a need for further work to constrain the flux of air through karst systems.

The thermal response of a karst massif to change in climate has also been considered using simple models (Badino 2004). The temperature of a karst massif is roughly equal to the average temperature of the fluids that cross it. However, if climate is changing, then the temperature of these fluids may also change with time. Since the karst massif has a large heat capacity, this change will not be instantaneous and will occur over some timescale. Badino (2004) suggests that a timescale of particular interest is heat capacity timescale, which is the time over which the heat capacity of the fluids crossing the massif is equal to the heat capacity of the rock within the massif. This can be written as

$$
\tau_{\text {cap }}=\left(\frac{c_{\mathrm{r}} \rho_{\mathrm{r}}}{c_{\mathrm{f}} \rho_{\mathrm{f}}}\right) \frac{H}{R},
$$

where $c_{\mathrm{r}}$ and $c_{\mathrm{f}}$ are the specific heat capacities of the rock and fluid (water or air), $\rho_{\mathrm{r}}$ and $\rho_{\mathrm{f}}$ are the densities of the rock and fluid, $H$ is the thickness of the massif, and $R$ (dimension of $\mathrm{L} / \mathrm{T}$ ) is the flux of water or air. In the case of water, annual recharge can be used for $R$. The ratio in parentheses in Equation 1 is roughly equal to 0.5 for water and 1500 for air. Considering recharge by water at a rate of $1 \mathrm{~m} \mathrm{yr}^{-1}$ would lead to a heat capacity timescale of 50 years for a rock thickness of $H=100 \mathrm{~m}$ and 500 years for a thickness of $H=1000 \mathrm{~m}$. These values would suggest that the massif would lag behind local climate changes by the order of a few hundred years. However, there are other potentially relevant timescales. In particular, as also noted by Badino (2004), a temperature pulse will propagate into a rock body via conduction to a depth $H$ over a timescale given by

$$
\tau_{\text {cond }} \sim H^{2} / \alpha_{\mathrm{r}},
$$

where $\alpha_{\mathrm{r}}$ is the thermal diffusivity of rock $\left(\sim 10^{-6} \mathrm{~ms}^{-1}\right.$ for dry rock). In order for the entire massif to change temperature there are two requirements: 1) the heat capacity of the fluids that have crossed it has to be comparable to or greater than the heat capacity of the massif, and 2) the temperature must have time to conduct away from areas of fluid contact and through the body of the rock. Therefore, if the conduction timescale is much longer than the heat capacity timescale, it would suggest an influence of conduction on the response time of the karst massif. In fact, Equation 2 implies quite long timescales for the equilibration of large thicknesses of rock. For example $H=1000 \mathrm{~m}$ would lead to an equilibration time scale of $\tau_{\text {cond }} \sim 3 \times 10^{4} \mathrm{yr}$. However, because of the network of conduits that penetrate the aquifer, it is unlikely that heat within a karst aquifer will need to conduct through its 


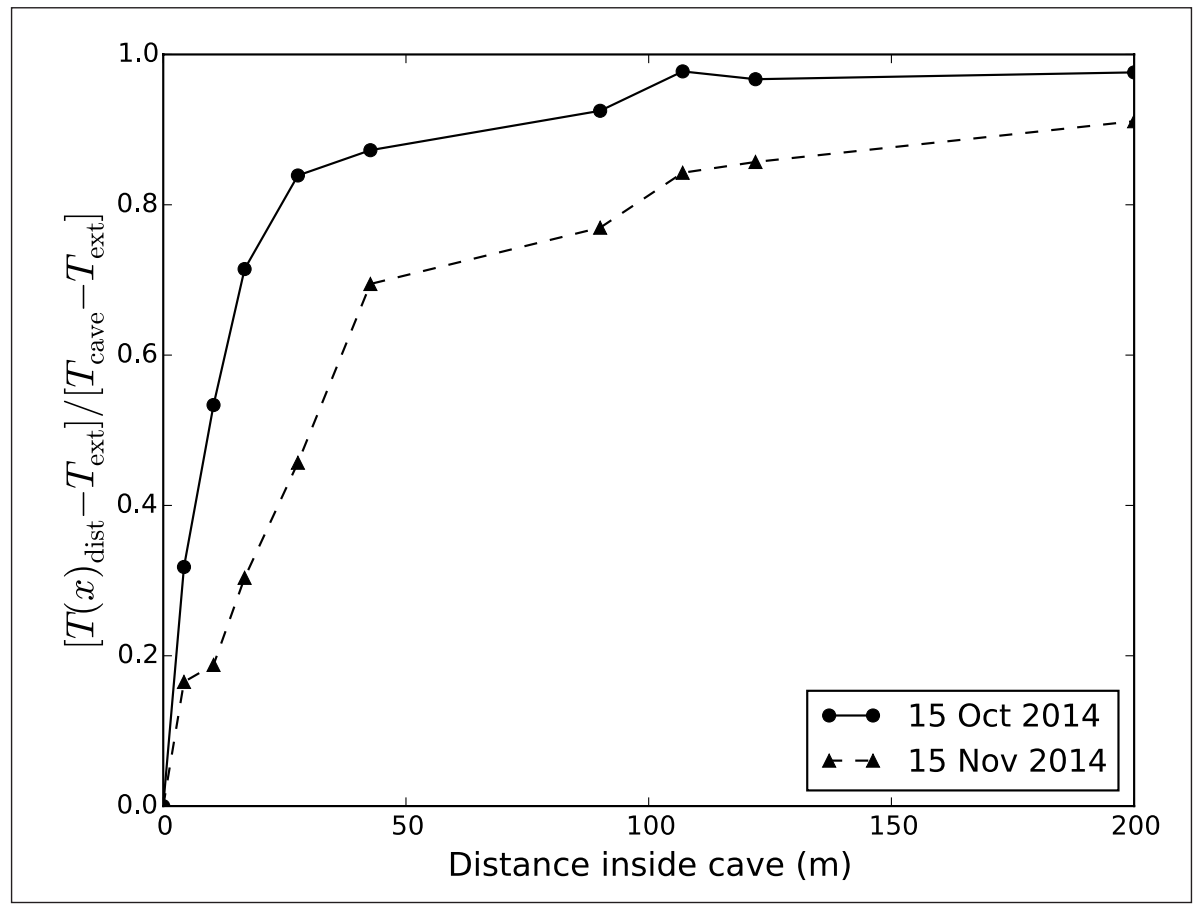

Fig. 2: Air temperature in Blowing Springs Cave, Arkansas, USA, as a function of distance into the cave. Later in the winter, cold outside air penetrates deeper than in the late fall. Temperature profiles are shown as the difference between cave temperature and external temperature normalized by the difference between equilibrium cave temperature and the external temperature. This shows that cooling is not simply a result of cooler outside temperature but rather an increase in the thermal penetration length.

entire thickness. Therefore, half of typical distance between large conduits may be a more appropriate value for $H$ than the entire aquifer thickness.

These two timescales assume a decoupling between conduction and heat exchange due to fluid flow. Equation 1 makes an assumption that the fluids are able to exchange all available heat, whereas Equation 2 assumes that the temperature at the fluid rock boundary is coupled to the surface temperature. The processes of fluid heat exchange and conduction are actually coupled, and their coupling leads to a third relevant timescale, which is the timescale over which a thermal pulse can propagate a given distance, $L$, down a conduit imbedded in rock,

$$
t_{\text {coupled }} \approx \frac{16 \alpha_{\mathrm{r}} L^{2}}{\pi \Psi^{2} D_{\mathrm{H}}^{2} V^{2}},
$$

where $\Psi=\left(\rho_{\mathrm{f}} c_{\mathrm{p}, \mathrm{f}}\right) /\left(\rho_{\mathrm{r}} c_{\mathrm{p}, \mathrm{r}}\right)$ is the ratio of the densities and specific heat capacities of the fluid and rock, $D_{\mathrm{H}}$ is the conduit hydraulic diameter, and $\mathrm{V}$ is the fluid flow velocity. This can be derived from the thermal length scale given in Equation 22 of Covington et al. (2012b). In general, thermal pulses do not move down conduits at the same velocity as the fluid. This results because of exchange of heat between the fluid and rock. The pulse is damped as it flows along the conduit, but over time the rock cools or heats and the thermal pulse propagates further. This pulse propagation timescale may be the most important one to determine the long-term temperature behavior of rock immediately surrounding conduits and the fluids within the caves themselves. Though an overall picture has emerged, a variety of questions remain unexplored regarding the importance of these different timescales, and the internal aquifer structure, in determining the long-term thermal behavior of karst aquifers.

\section{HEAT EXCHANGE WITHIN KARST CONDUITS}

Covington et al. (2011) explored the relative importance of mechanisms of heat exchange in karst conduits, as there were inconsistencies between prior models of karst conduit heat exchange. Some models assumed that heat exchange was limited by convective exchange in the boundary layer near the wall (Wigley \& Brown 1971; Long \& Gilcrease 2009), other models assumed that heat conduction within the wall was limiting (Benderitter et al. 1993), and others accounted for both processes (Liedl \& Sauter 1998; Birk et al. 2006). Covington et al. (2011) showed that the relative importance of convective and conductive heat exchange is determined by a critical time scale

$$
t_{\text {conv }} \approx \frac{k_{\mathrm{r}}^{2} D_{\mathrm{H}}^{2}}{k_{\mathrm{w}}^{2} \alpha_{\mathrm{r}} \mathrm{Nu}^{2}},
$$

where $k_{\mathrm{r}}$ and $k_{\mathrm{w}}$ are the thermal conductivities of rock and water, respectively, $D_{\mathrm{H}}$ is the hydraulic diameter of the conduit, $\alpha_{\mathrm{r}}$ is the thermal diffusivity of rock, and $\mathrm{Nu}$ is the Nusselt number. For temperature pulses with 


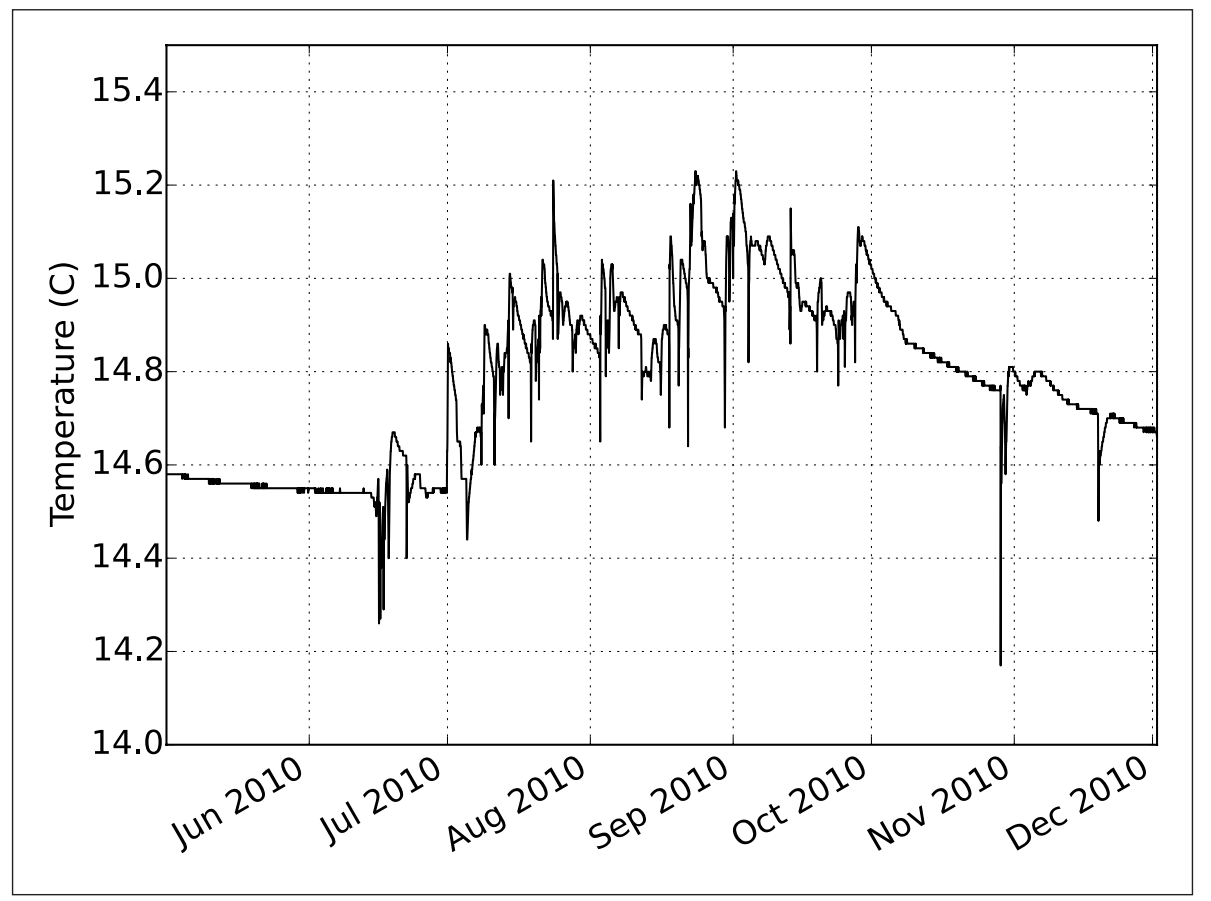

Fig. 3: Temperature time series from near Camp 3 in Sistema $\mathrm{J} 2$ at a depth of approximately $-1100 \mathrm{~m}$ demonstrate a complex variability with time throughout the wet season.

timescales $t_{\text {pulse }} \ll t_{\text {conv }}$ heat exchange is limited by convective exchange in the boundary layer. For $t_{\text {pulse }} \gg t_{\text {conv }}$ heat exchange is limited by conduction. A parameter search shows that $t_{\text {conv }}$ is typically on the order of a fraction of a second to a few tens of seconds for the flow conditions expected in most karst conduits. This suggests that models assuming convection-limited heat exchange will typically drastically overestimate the exchange rate. Prior models of heat exchange had not considered radiative or air-mediated exchanges that might occur in open channel karst conduits. Simple estimations suggest that air-mediated exchanges are not particularly important, except perhaps near entrances. On the contrary, radiative heat exchange can be substantial (Covington et al. 2011).

To our knowledge, only one physics-based mathematical model has been produced of air temperature profiles within the entrance zone of an inwardly drafting cave entrance (Wigley \& Brown 1971, 1976). They find a characteristic exponential length scale over which air temperature decays toward the equilibrium cave temperature. However, this model is also built on the assumption of constant rock temperature, which is equivalent to the assumption that heat exchange is limited by the convective boundary layer. The time scale given by Equation 4 applies directly, if the fluid properties of air are substituted for water. Making the substitutions, one finds that typical values of $t_{\text {conv }}$ for air-rock heat exchange are on the order of a few days, assuming airflow velocities on the order of $1 \mathrm{~m} \mathrm{~s}^{-1}$. This analysis suggests that the penetration depths estimated by Wigley \& Brown
(1971) are underestimates, at least for long time scales. Gradual cooling of the rock should lead to evolution of the penetration depth with the square root of time (Covington et al. 2012b). In fact, recent observations in Blowing Springs Cave, Arkansas, USA, suggest an evolving penetration length over the winter (Fig. 2).

Models of heat exchange within karst conduits have typically considered short time scales (Benderitter et al. 1993; Liedl \& Sauter 1998; Birk et al. 2006; Covington et al. 2012b, 2011; Luhmann et al. 2012, 2015), such as those associated with single recharge events or diurnal or seasonal variations. Furthermore, they have typically neglected the interactions between air and water (Covington et al. 2011) that become important within deep vadose zones. In contrast, as discussed above, models of cave temperature with depth (Luetscher \& Jeannin 2004; Badino 2010), and aquifer heat exchange over long periods (Badino 2004, 2005) have not typically considered longitudinal effects within the conduits, the geometry of the conduit-rock interface, or the extent to which air and water temperature deep within the aquifer vary with time. A model that combines the whole aquifer and conduit-based approaches might lead to important new understanding about heat transport within karst massifs. Intriguing clues are provided by a water temperature time series from Sistema J2, Oaxaca, Mexico (Fig. 3). The data were recorded near a depth of $-1100 \mathrm{~m}$, which is well below the zone of thermal variability (Luetscher \& Jeannin 2004), and the system is recharged autogenically. Nevertheless, during the wet season (June-Oct) the cave stream exhibits relatively complex temperature 


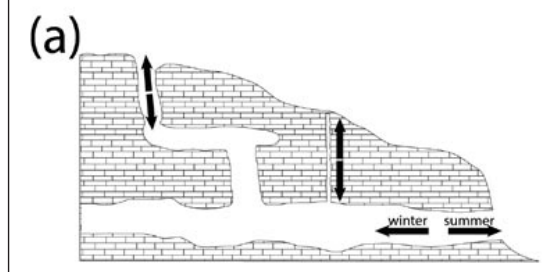

(b)

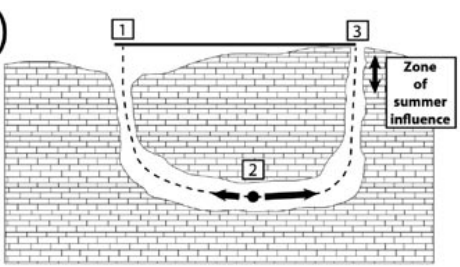

(c)

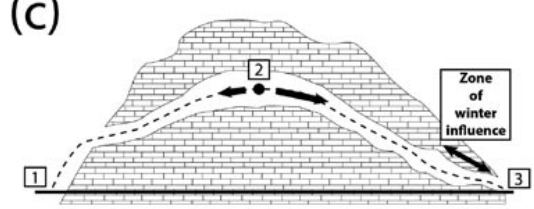

(d)

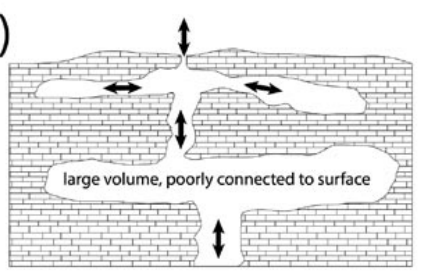

(e)

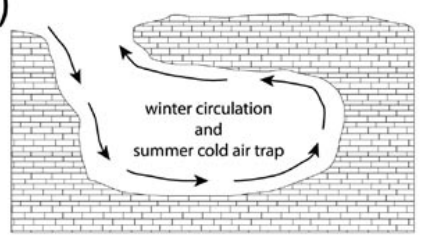

(f)

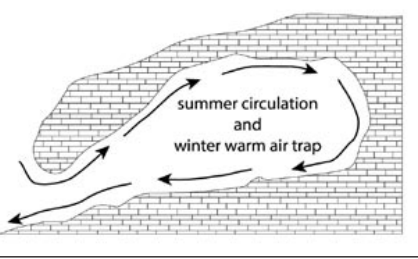

Fig. 4: Illustrations of mechanisms for cave airflow. For thermally driven flows, airflow direction during cold external temperatures (winter) is shown in gray and warm external temperatures (summer) in black. (a) Chimney effect airflow occurs in caves with multiple entrances at different elevations. It can also occur in fractures or flow paths that are not humanly accessible. When the entrances have small elevation differences between them, chimney effect flows may be more effective in winter (b) or summer (c) depending on the cave geometry and the depth of external temperature influence. d) Barometric airflows dominate in caves that contain large volumes but are poorly connected to the surface, such as hypogene maze caves. Circulating winter (e) and summer $(f)$ convection cells frequently occur near large entrances. The relative elevation of the entrance and cave void determines whether convection is active in the winter or summer. dynamics with a total amplitude of about $1{ }^{\circ} \mathrm{C}$. There is a gradual warming pattern associated with the wet season recharge, which occurs during the local summer. Most storm events produce short, cold temperature pulses that precede a larger warm pulse with a relatively linear recession. These patterns may indicate an interplay between vertical thermal profiles and the introduction of warm recharge event water. As an event begins, cold high-elevation water is brought more quickly to depth; however, the warm event water ultimately warms the conduits sufficiently for the heat to penetrate to great depths. The gradual warming pattern may indicate aquifer warming over the wet season that results from the frequent warm recharge. These processes are not captured by the current generation of heat flow models.

\section{CAVE AIRFLOW}

Variability within a cave atmosphere is primarily driven by external pressure and temperature changes that alter cave airflow, though variations in stream discharge and temperature can also drive changes in the cave atmosphere. A variety of mechanisms have been identified that produce cave airflow (Cigna 1968; Wigley \& Brown 1976) including: chimney effect airflow, circulating convective airflow, barometric airflow, water entrainment airflow, airflow due to floodwaters changing the volume of air within the system, and surface wind driven flow (Fig. 4). Among these, chimney effect airflow is suggested to be the most ubiquitous and important mechanism (Wigley \& Brown 1976; Luetscher \& Jeannin 2004; Badino 2010).
Chimney effect airflow is present in multi-entrance caves (Fig. 4a-c), where density differences between cave air and outside air, largely controlled by temperature differences, produce flow between lower and upper entrances. When outside temperature is colder than cave temperature, cave air is light and buoyantly rises out upper entrances while outside air is drawn in the lower entrances. During warm external temperatures, the cave air is dense compared to outside air and falls out the lower entrances, pulling outside air into the upper entrances. It is important to note that such airflow patterns do not require that a cave have multiple human-sized entrances. Substantial airflows can be driven through much more restricted pathways, such as fractures, soil, or highly permeable rock, and may add up to a significant total flux (Wigley \& Brown 1976; Spötl et al. 2005; Covington in press). Large elevation differences between entrances are also not required. A few meters (Luetscher et al. 2008) or tens of centimeters (Covington in press) elevation difference between entrances is sufficient. We are unaware of any systematic studies of cave airflow mechanisms to examine their relative importance. However, it is the authors' personal observation from visiting hundreds of caves that most caves above some minimum size (perhaps a few hundred meters to a kilometer) exhibit airflow patterns that can be explained by the chimney effect. The primary exception to this seems to be hypogene cave systems, which can have very large cave volumes and often only small, accidental, connections to the surface. In these systems, barometric winds are often dominant (Fig. 4d). 
Despite seasonal alteration of flow direction, chimney effect airflow does not necessarily imply uniformity in exchange rates of air between the surface and cave atmospheres in the summer and winter. Buecher (1999) observed a contrast in summer and winter airflow velocities in Kartchner Caverns that is thought to result from geothermal warming of the cave, such that temperature contrasts between the cave and surface, and consequently airflow velocities, are substantially greater in the winter than in the summer. Contrasts in the moisture and $\mathrm{CO}_{2}$ content of surface and cave air can also produce asymmetry between summer and winter airflow velocities (S'anchez-Ca nete et al. 2013). For caves with relatively small elevation differences between entrances, the cave geometry can also produce seasonal asymmetry in airflow velocity. If the cave passage connecting the two entrances extends substantially below (Fig. 4b) or above (Fig. 4c) the elevation of both entrances, then penetration of outside air into the inward drafting entrance can reduce the pressure gradient and slow, or even halt, chimney effect flows. In Fig. $4 \mathrm{~b}-\mathrm{c}$ the columns of air between points 1 and 2 and points 3 and 2 must have an imbalance in weight in order for chimney effect airflow to be active. This imbalance will be enhanced in one season and reduced or eliminated in the other if the zone into which external air temperatures penetrates extends sufficiently far into the cave mouth in comparison to the elevation difference between the entrances. This seasonal pattern is observed by Luetscher et al. (2008), where chimney effect flow is only active in the winter.

Circulating, typically local, convection currents can also be driven by temperature differences (Fig. 4e-f). Most frequently such currents occur near large entrances that can simultaneously accommodate flow into and out of the subsurface void. If the cave has a downward trend (Fig. 4e) from the entrance, then such currents are active during cold outside temperature, with cool, dry air sinking in along floor level and warmer moister air rising outward along the ceiling. If the cave trends upward from the entrance (Fig. 4f), then such currents are active during warm surface temperatures. In both cases, the circulating convection acts to reduce the difference between atmosphere and cave rock temperatures over time. Therefore, at constant outside temperature, such convection cells will gradually shut off as cave rock temperature approaches the outside temperature. The timescale over which convection cells shut off is not known but will depend in part on the surface area of rock that is changing temperature. Chimney effect flow that is only active in the winter, or circulating convection cells near entrances, sometimes lead to the formation of cold air traps, particularly in smaller caves that are not well-connected to a larger system. In sufficiently cold climates, such caves can form permanent deposits of ice, even if average temperatures are above freezing (e.g. Luetscher et al. 2008). A similar cold zone can also form near lower entrances in caves that experience chimney effect flows, as such entrances will receive a substantial influx of cold outside air during winter, and will be isolated from the outside air during summer.

\section{CARBON DIOXIDE DYNAMICS WITHIN KARST VADOSE ZONES}

One of the important implications of cave airflow patterns is their influence on $\mathrm{CO}_{2}$ concentrations within the subsurface atmosphere and water. $\mathrm{CO}_{2}$ is produced within the subsurface via a variety of processes, including root respiration and the decay of organic matter. Consequently, $\mathrm{CO}_{2}$ concentrations in cave air are typically higher than atmospheric levels, and an important control on these concentrations is the rate of air exchange between the surface and subsurface. Seasonally alternating stability of the cave atmosphere, as produced by local convection (Fig. 4e), has recently been used to explain seasonal changes in $\mathrm{CO}_{2}$ concentrations in caves and other subsurface voids that display low $\mathrm{CO}_{2}$ concentrations in the winter and high concentrations in the summer (Banner et al. 2007; Weisbrod et al. 2009; Serrano-Ortiz et al. 2010; Breecker et al. 2012; James et al. 2015). It is inferred that the voids have higher exchange rates with the surface atmosphere during winter than in summer. However, similar dynamics might be observed in the case of chimney effect flows (Fig. 4a), particularly near lower entrances. In fact other researchers have seen seasonal $\mathrm{CO}_{2}$ variability that was attributed to bi-directional chimney effect flows (Buecher 1999; Spötl et al. 2005). In most cases, these two airflow mechanisms are not clearly discriminated in the literature; however, the difference between chimney effect and local circulating convective flows is potentially important, as the two airflow mechanisms lead to quite different spatiotemporal patterns in cave atmospheric dynamics and resulting $\mathrm{CO}_{2}$ concentrations. For local, circulating flows, seasonal changes in $\mathrm{CO}_{2}$ result from a contrast in exchange rates between the atmosphere and subsurface voids due to thermal conditions that are either stable or unstable to local convection. Changes in $\mathrm{CO}_{2}$ concentration in this case will often be quite isolated near entrances. In the chimney effect case, seasonal $\mathrm{CO}_{2}$ variability at a given location relates to the direction of airflow relative to zones of high and low $\mathrm{CO}_{2}$ concentrations, the underground residence time of the air, and changes in $\mathrm{CO}_{2}$ production rate with season. For chimney effect caves, systematic gradients in $\mathrm{CO}_{2}$ concentrations along flow paths between upper and lower entrances would be expected, as well as contrasting temporal dynamics 
in zones near upper, lower, and intermediate elevation entrances.

It is clear that cave airflow patterns are an important control on $\mathrm{CO}_{2}$ dynamics in karst systems, and also are important for the relationship between external and cave climates. However, the relative importance of different airflow mechanisms is poorly quantified. Theoretical studies have not typically gone beyond simple mathematical formulations that describe chimney effect and barometric airflow. There are also few quantitative longterm studies of cave airflow. Further theoretical studies and field investigations will help quantify the relative importance of cave airflow mechanisms. This will have important implications for speleothem paleoclimate studies (Spötl et al. 2005; Banner et al. 2007; Breecker et al. 2012), global carbon dynamics (Serrano-Ortiz et al. 2010), and the evolution of karst over time (Wood 1985; Gulley et al. 2013, 2014; Covington in press).

\section{KARST FLOW AND TRANSPORT}

Another area of research that has benefited from the physicist's toolbox is that of flow and transport in karst aquifers, particularly as it relates to the interpretation of the signals observed at karst springs. It has long been realized that the variations in flow, temperature, and chemistry observed at karst springs can carry information about the geometry of the conduit system (Ashton 1966). The central difficulty in attempting to model a specific karst aquifer is the lack of information about the location and properties of the conduits. Therefore, any information that can be obtained from external observations is potentially valuable.

\section{DISCHARGE DYNAMICS}

Perhaps the most work on spring variability has analyzed the discharge hydrographs of karst springs. A common approach has been to use functional fitting, systems analysis, simple reservoir models, and time series analysis to characterize dynamics and, in some cases, make inferences about aquifer structure (e.g. Maillet 1905; Dreiss 1982; Padilla \& Pulido-Bosch 1995; Labat et al. 2000; Geyer et al. 2008). In a review of such techniques, Jeannin \& Sauter (1998) conclude that hydrograph analysis is somewhat limited in the information that it can provide about aquifer structure, in part because of the strong influence of the temporal distribution of recharge on spring hydrograph behavior. Process-based simulations of flow in karst aquifers have also been used to explore system dynamics (e.g. Eisenlohr et al. 1997; Halihan \& Wicks 1998; Kovacs et al. 2005; Reimann et al. 2011). However, the detail with which physical structure can be specified in these models is also a hindrance to generalization. The disadvantage of the systems analysis, reservoir models, and statistical approaches is that the connection between the results and mechanistic understanding is weak, and sometimes misinterpreted (e.g. Eisenlohr et al. 1997). For the mechanistic models, the connection to physical processes is clear, but at the expense of being difficult to generalize beyond a few simulated cases. Here we think that the physicist has something to offer as a bridge between these two approaches. In particular, simple models, dimensional analysis, and the illumination of characteristic length scales and timescales can provide a powerful framework to generalize the results of simulations. Similarly, it can enhance our physical understanding of the results from black box and statistical models.

The question of the information content of hydrographs, and the extent to which they reflect properties of the system versus the properties of the recharge, has been approached in this manner. Covington et al. (2009) derive characteristic response times for different components of the karst hydrological system, including full pipes, open channels, and reservoirs drained by a full pipe. They show that the modification of the hydrograph by the individual components of the system is dependent on a dimensionless parameter that is a ratio between the hydraulic response time of that component and the timescale over which recharge is varied. When the timescale of recharge variation is comparable to or longer than the hydraulic response time then hydrographs are strongly controlled by the functional shape of the recharge. Hydraulic response times are primarily a function of the geometrical properties of the conduits and reservoirs. This work was later expanded and applied to glacial conduit systems, and some of the complexities of network junctions and hydraulic damming were explored (Covington et al. 2012a). The broad message of this work was that, under typical conditions, spring hydrographs should carry little information about the conduit network itself, as these hydrographs tend to be strongly controlled by the rate of recharge into the conduit system. On the other hand, if large free-surface reservoirs with down-gradient constrictions are present, then the hydrographs can reflect the structural properties of these features. 
While hydrographs can be quite limited in the information content they carry about the conduit network, thermal and chemical tracers are more promising, as they relate to the surface area of interaction along the flow path (Benderitter et al. 1993; Liedl \& Sauter 1998; Grasso \& Jeannin 2002). The first complete simulations of transport through a karst aquifer that aimed at examining spring signals were conducted by Birk et al. (2006). These simulations allowed quantification of the accuracy of volume estimates made using the approach described by Ashton (1966), and also allowed an initial exploration of the dynamics of such signals. However, results concerning the information content of such signals remained difficult to generalize.

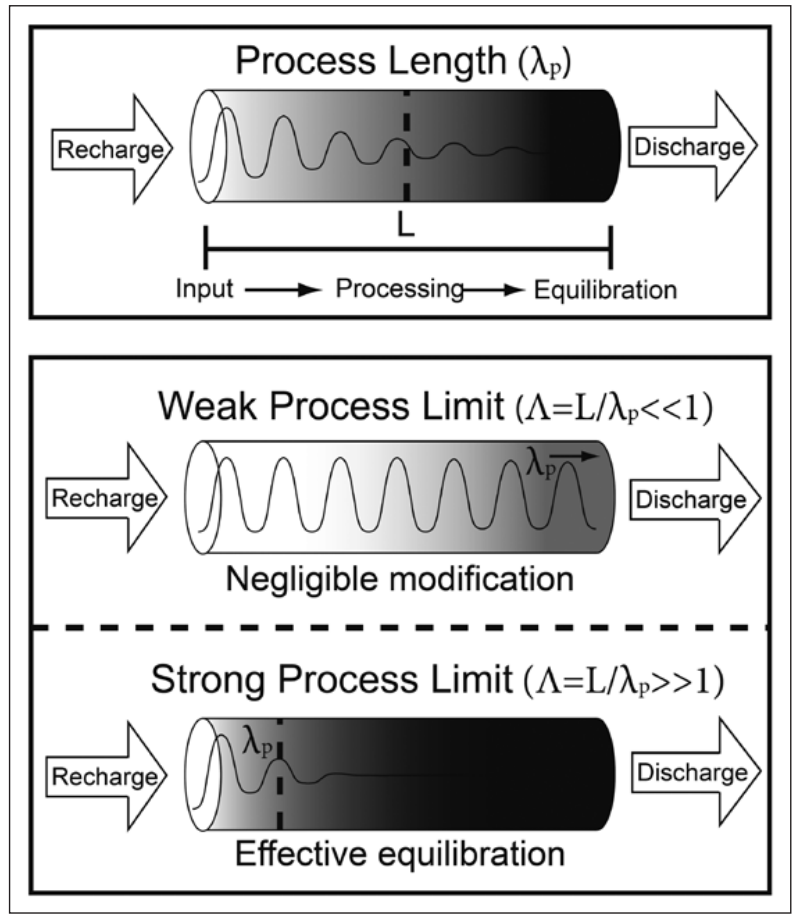

Fig. 5: Process length scales and the propagation of signals through karst conduits. When the process number, $\Lambda$, is small, signals are barely damped (the weak process limit) and when $\Lambda$ is large, signals are entirely damped (the strong process limit). If the process length is a function of conduit geometry, then maximum information about conduit geometry can be obtained when $\Lambda \sim 1$. Figure reproduced from Covington et al. (2012b).

\section{TRANSPORT AND PROCESS LENGTH SCALES}

To build a more general mathematical framework to understand the information content of chemical and thermal spring signals, Covington et al. (2012b) derived the process length scales that are associated with the propagation of signals through karst conduits. The ability of a conduit to transmit a given signal can be quantified using the ratio of conduit length $\mathrm{L}$ to the length scale associated with the process $\lambda_{\mathrm{p}}, \Lambda=L / \lambda_{\mathrm{p}}$, which Covington et al. (2012b) refer to as the process number. In the limit where $\Lambda \ll 1$ the signal will not be modified by the conduit, and in the limit where $\Lambda \gg 1$ the signal will be entirely damped before exiting the conduit (Fig. 5). $\Lambda$ allows characterization of the information content of spring chemical and thermal signals. In a case where input and output signal amplitudes are known, the maximum information can be obtained if $\Lambda \sim 1$, that is when the signal is modified by the system but not entirely damped.

Within conduits sufficiently large for turbulent flow, conductivity signals behave relatively conservatively $(\Lambda \ll 1)$. Consequently, longitudinal increases in conductivity along a cave stream are often a good indicator of diffuse input with a higher dissolved load. On the contrary, temperature signals are relatively easily damped, even in large conduits. Because of this, temperature signals often carry substantial information about conduit geometry $(\Lambda \sim 1)$. The transmission of temperature signals is also dependent upon the timescale of the temperature variation. Temperature variations with longer timescales will penetrate further along a conduit as the surrounding rock heats or cools. A few simple approximations emerge from the derivation of thermal length scales. For short duration pulses, with a timescale less than approximately $t_{\mathrm{tr}}=\pi \Psi^{2} \mathrm{D}_{\mathrm{H}}^{2} /\left(64 \alpha_{\mathrm{r}}\right)$, the thermal penetration length is given by

$$
\lambda_{\text {T,early }}=\overline{\mathrm{V}} t \text {, }
$$

where $\overline{\mathrm{V}}$ is the average flow velocity, $t$ is the timescale of temperature variation, and $\Psi=\left(\rho_{\mathrm{w}} c_{\mathrm{p}, \mathrm{w}}\right) /\left(\rho_{\mathrm{r}} c_{\mathrm{p}, \mathrm{r}}\right)$ is the ratio of the densities and specific heat capacities of water and rock. Equation 5 shows that a temperature pulse will be substantially damped when its duration is similar to or much less than the flow-through time. For typical thermal parameters, $t_{\mathrm{tr}}$ is approximately $2.5 \mathrm{D}_{\mathrm{H}}^{2}$ days, where $D_{\mathrm{H}}$ is in meters. For longer term variations $\left(t \gg t_{\mathrm{tr}}\right)$, the thermal length scale becomes

$$
\lambda_{\mathrm{T}, \mathrm{late}} \approx \sqrt{\frac{\pi t}{\alpha_{\mathrm{r}}}} \frac{\Psi D_{\mathrm{H}} \overline{\mathrm{V}}}{4},
$$

Here the penetration length scales with the square root of the timescale of the temperature variation, which is common in many heat conduction solutions.

Calculation of the fraction of a signal that is transmitted through an individual conduit segment can be scaled up to conduit networks if the signal behaves linearly, that is, if the fraction transmitted is a linear function of the amplitude of the signal. This is the case for linear dissolution kinetics, but the propagation of 
thermal pulses is inherently non-linear. Covington et al. (2012b) show that the propagation of thermal pulses can be linearized, and that this is a good approximation in cases that are not too heavily damped. The extent to which this approach approximates the behavior in real karst networks is uncertain.

Since thermal pulses provide the most promise in constraining the properties of the conduit network, a series of simulations and field experiments were devised that used simultaneous thermal and conservative tracer pulses to probe conduit geometry (Luhmann et al. 2012). Luhmann et al. (2015) provided a more general mathematical framework for understanding the propagation of thermal pulses. Thermal pulses are both damped and retarded in comparison to a conservative tracer. The damping and retardation are both correlated to conduit diameter. Specifically, we showed that the solution for sinusoidal temperature variations provides a close approximation to the damping and retardation experienced by an isolated pulse. This leads to explicit relations for the damping and retardation of thermal pulses that are a function of the hydraulic diameter, the flow-through time, the duration of the pulse, and the thermal properties of water and rock. In principle, this theoretical development enables estimation of conduit diameters using artificial tracer experiments or observations of natural variations. Initial results suggest that this approach can be applied in real conduits.

\section{SPELEOGENESIS}

The study of speleogenesis is perhaps the field where those with a background in physics have made the largest contribution to cave and karst science. A variety of mechanistic numerical models have been developed, based on rate laws and conservation equations that couple water flow, transport of dissolved species, and dissolution of the rock (Dreybrodt 1988; Dreybrodt et al. 2005a). This work began with extensive dissolution experiments (Plummer et al. 1978) and the development of a theory for coupled dissolution and transport processes that was used to interpret the experimental results and formed the basis for later speleogenesis models (Buhmann \& Dreybrodt 1985a,b; Dreybrodt \& Buhmann 1991).

\section{FRACTURE-BASED MODELS}

The earliest speleogenetic models were one-dimensional (1D) models of evolution of a single fracture (Dreybrodt 1988; Palmer 1991; Dreybrodt 1996). These models allowed calculation of dissolution length scales, demonstrated the importance of non-linearities in dissolution rate laws, illustrated the action of positive feedback loops, and form the basic elements of more complex models. An important contribution of the single fracture models was the development of the concept of breakthrough time, which is the time needed to significantly enlarge the downstream end of the fracture, when positive feedback causes runaway fracture growth. Dreybrodt (1996) used many fracture model simulations to develop an empirical relationship for breakthrough time as a function of the relevant parameters:

$$
T=C\left(\frac{L}{\nabla h}\right)^{4 / 3} \frac{k_{\mathrm{n} 2}^{1 / 3}}{a_{0}^{3} C_{\mathrm{eq}}^{4 / 3}},
$$

where $L$ is the conduit length, $\nabla h$ is the hydraulic gradient, $a_{0}$ is the initial aperture, $k_{\mathrm{n} 2}$ is the kinetic rate constant for non-linear calcite dissolution near equilibrium (dimension of $\mathrm{L}^{-2} \mathrm{~T}^{-1} \mathrm{~N}$ ), and $C_{\text {eq }}$ is the equilibrium concentration of calcite (dimension of $\mathrm{L}^{-3} \mathrm{~N}$ ). $\mathrm{C}$ is a constant that depends on the shape of the conduit and is approximately equal to $6.1 \times 10^{-3} \mathrm{~m}^{-5 / 3} \mathrm{~mol} \mathrm{~s} \mathrm{~s}^{4 / 3}$ for square and circular cross sections and $6.1 \times 10^{-4} \mathrm{~m}^{-5 / 3} \mathrm{~mol} \mathrm{~s}^{4 / 3}$ for fracturelike cross sections. The scalings seen in Equation 7, were also reproduced with an analytical approximation (Dreybrodt 1996; Dreybrodt \& Gabrovšek 2000) and arguably provide us with the deepest understanding that we currently have about the timescale of karstification and the factors that control it.

More complex dynamics arise as one moves from 1D fractures to two-dimensional (2D) representations of fractures or 2D networks of fractures. Hanna \& Rajaram (1998) showed that aperture heterogeneity within a fracture can result in the formation of preferential flow paths that accelerate breakthrough in comparison to the $1 \mathrm{D}$ case. Similarly, exchange flows between fractures and matrix, or larger and smaller aperture fractures within a network, can also accelerate breakthrough (Bauer et al. 2003; Gabrovšek et al. 2004). Szymczak \& Ladd (2011) demonstrate that the propagation of a dissolution front within a fracture is fundamentally unstable, which results in fingering of the dissolution front. The instability accelerates breakthrough, but a newer formulation 
of breakthrough time that accounts for these effects remains elusive (Szymczak \& Ladd 2012).

Simulations of the evolution of $2 \mathrm{D}$ fracture networks have enabled studies of the evolution of cave plan forms (Groves \& Howard 1994; Siemers \& Dreybrodt 1998) and cave profiles (Gabrovšek \& Dreybrodt 2001). Such models have been used to explore the competition between different flow paths and the influence of mixing corrosion (Gabrovšek \& Dreybrodt 2000), the effect of $\mathrm{CO}_{2}$ sources (Gabrovšek et al. 2000), the formation of flank margin caves (Dreybrodt \& Romanov 2007; Dreybrodt et al. 2009), buoyant convection (Chaudhuri et al. 2009), and karstification around dam sites (Dreybrodt et al. 2002). Double-porosity models, where flow through discrete conduits is coupled to the flow through porous rock matrix, have also been developed (Kaufmann \& Braun 2000; Liedl et al. 2003). Kaufmann (2009) introduced a three-dimensional karst evolution model that coupled speleogenesis and landscape evolution. For a comprehensive review of fracture network speleogenesis models, which also presents some novel results, see Dreybrodt et al. (2005a).

\section{THE NEXT GENERATION OF SPELEOGENESIS MODELS}

Speleogenetic models have primarily focused on the early stages of cave formation and the dynamics of flow network initiation. However, there is a rich host of processes that occur in the later stages of speleogenesis that have received little modeling attention. We have only recently seen the first network speleogenetic models that consider the transition to open channel flow and its potential role in preferential selection of flow paths (Perne et al. 2014b). Mature cave systems often develop undercapture routes, though this will only happen if lower routes are able to enlarge quickly enough to outpace the downcutting of the active stream passage. Gabrovšek et al. (2014) derive a dimensionless number, called the Loop-to-Canyon-Ratio, that is the ratio of the timescales for breakthrough of the lower passage and downcutting of the active stream passage. They use this ratio to explore the controls on multi-level cave development and cave evolution within the epiphreatic zone.

Turbulent flow dominates the later stages of cave formation. There are unresolved questions concerning dissolution rates under turbulent conditions (Hammer et al. 2011; Covington 2014). Direct application of the theory would suggest that surface reaction rates are limiting under turbulent flow conditions. However, scallops and flutes are features that strongly suggest that dissolution rates are a function of flow structure (Blumberg \& Curl 1974). It may be that chemomechanical processes play an important role, whereby individual grains are chemically loosened and then mechanically plucked. High resolution scanning of dissolving surfaces suggests that grain detachment may strongly influence rates of erosion (Emmanuel \& Levenson 2014).

Whether or not chemo-mechanical erosion processes are important, mechanical erosion is certain to be important in more powerful cave streams (Newson 1971). However, little is known about controls on the relative importance of chemical and mechanical erosion processes in cave streams, and models have not yet included mechanical processes. Mechanical erosion processes typically scale with the shear stress to a power of 1 to 3 (Whipple et al. 2000). In contrast, transport limited dissolution scales with shear stress to the $1 / 3$ to $1 / 2$ power (Opdyke et al. 1987). The controls on the variability of dissolution rates in cave streams are not well understood, but preliminary work suggests that chemically driven changes in dissolution rates within surface streams tend to scale weakly with discharge (Covington et al. 2015). There is a broad push within the geomorphology community to develop mechanistic models of earth surface processes (Dietrich et al. 2003). Mechanistic models for erosion by bedload, abrasion, and plucking (Sklar \& Dietrich 2004; Chatanantavet \& Parker 2009; Lamb et al. 2008) may prove useful within the next generation of speleogenesis models. Prescriptions for sediment dynamics will also be required to simulate the later stages of cave evolution (Farrant \& Smart 2011).

There is substantial interest in quantifying the controls on bedrock channel widths, as width is one of the least understood degrees of freedom available to accommodate channel response to contrasts in rock properties, uplift, and climate (e.g. Montgomery \& Gran 2001; Finnegan et al. 2005; Yanites \& Tucker 2010). Cave channels provide an interesting environment to examine such questions. Records of channel evolution are often wellpreserved within caves, and many conceptual models have been developed to understand different cave passage cross sectional shapes (Lauritzen \& Lundberg 2000). The cross sections of fossil cave passages may provide clues to past hydrological or climatic conditions. Additionally, due to the absence of hillslopes, the dynamics of cave channel width may be somewhat simpler than surface channels. The records of channel evolution that are preserved underground may prove useful to constrain models of bedrock channel width more broadly. Speleogenesis models that incorporate cross-section evolution have only begun to be developed (Perne 2012; Perne et al. 2014a; Cooper et al. 2014, Fig. 6).

The formation and evolution of hypogene cave systems has seen increased attention in the recent past. However, little work has been done to quantitatively model such systems. Birk et al. (2005) examined the 


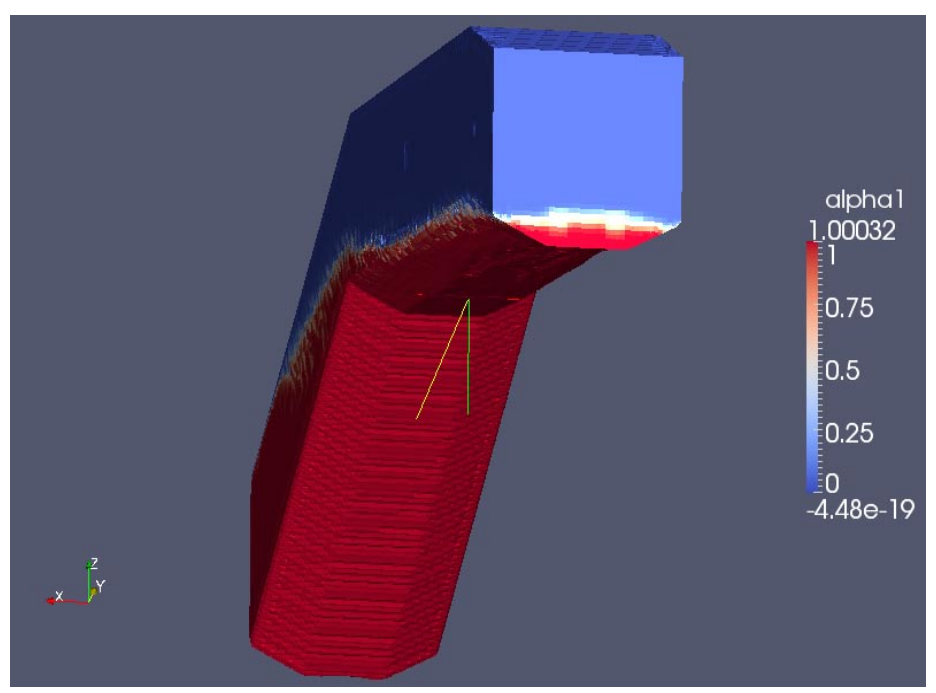

(a)

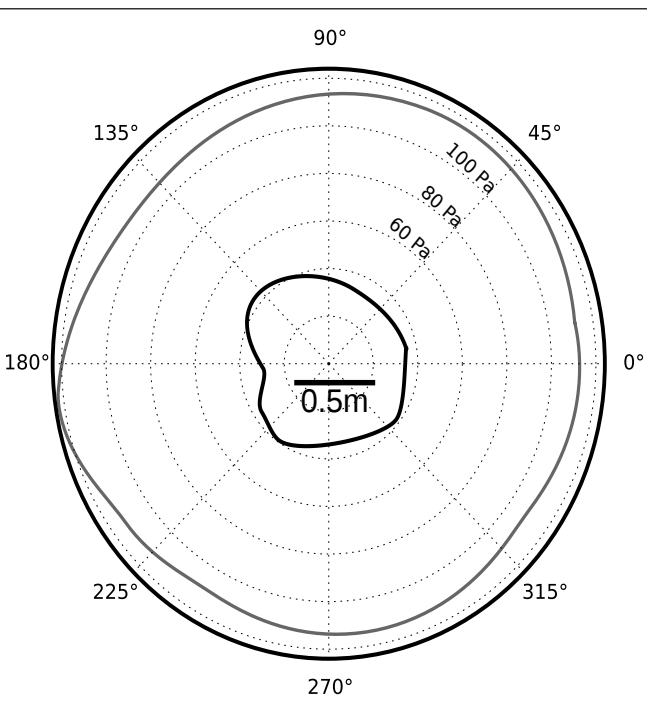

(b)

Fig. 6: Initial results from new models of cave channel cross section evolution that use calculations of boundary shear stress along the wall to evolve the channel. (a) A model that uses computational fluid dynamics to calculate shear stress (Perne et al. 2014a). Blue depicts air, and red depicts water. (b) A simpler model that approximates boundary shear stress along a conduit wall with an irregular shape (Cooper et al. 2014). The gray line shows boundary shear stress for the inset conduit cross-section with scale.

development of gypsum maze caves in an artesian setting, and a series of studies has examined dissolution under cooling and buoyantly driven flows (Andre \& Rajaram 2005; Chaudhuri et al. 2008, 2013). Little mathematical modeling work has been done on sulphuric acid speleogenesis. There is substantial debate in the karst community concerning hypothesized diagnostic features of hypogene speleogenesis, such as the morphologic suite of rising flow (Klimchouk 2007), and whether these features must form via deep rising flow or whether other processes such as condensation corrosion, freshwater/saltwater mixing, paragenesis, and flood water might produce similar features (Curl 1966; Mylroie 2008; Audra et al. 2009; Stafford et al. 2009; Palmer 2011). While conceptual models exist for the formation of these features, the proposed mechanisms have not generally been studied using mathematical models. Therefore the plausibility of the various mechanisms is uncertain from a physics perspective, and this area seems ripe for study using more mechanistically based models.

Another area of research where substantial advances are likely is the interaction between cave atmospheres and speleogenetic processes. Cave meteorology, in particular air flows, can influence the aggressivity of the water flowing through caves via exchange of $\mathrm{CO}_{2}$ between air and water (Covington et al. 2013). These effects have not yet been included in speleogenetic models. Coupled models of $\mathrm{CO}_{2}$ within cave air and water may first require further observational studies of cave streams and atmospheres to better quantify the controls on $\mathrm{CO}_{2}$ concentrations and their variability (Milanolo \& Gabrovšek 2015; Baldini 2010).

Meteorology also affects the formation of caves through condensation. The amount of condensed water can be significant (Dublyansky \& Dublyansky 2000), and as it initially contains dissolved carbon dioxide but no minerals it is typically fairly aggressive (Dreybrodt $e t$ al. 2005b). Condensation corrosion has been proposed to explain the formation of large cupolas (Audra et al. 2002). Condensation on cave walls occurs either continuously, in steady state, or periodically, as a result of temperature variations. Steady state condensation requires a source of water that is warmer than the surroundings (Sarbu \& Lascu 1997), and its rate is limited by heat conduction through the bulk of the rock away from the cave wall. The geometry of the cave and the surrounding rock has a strong influence on the rate (Dreybrodt et al. 2005b). In the case of periodic condensation, temperature variations cause heat to be stored in a layer of rock surrounding the cave and dispersed back during colder periods. During the periods when the air is sufficiently warm and moist and heat is being stored, condensation occurs. The total amount of condensation depends on the amplitude and frequency of the temperature signal, and the rock layer thickness required for heat storage is smaller for higher frequencies of temperature variations. Strong daily variations can, for example, cause significant condensation and corrosion even on speleothems (Tarhule- 
Lips \& Ford 1998). However, when the total amount of condensation per cycle is small, the water may not drip away but evaporate back during the drying period and re-precipitate the dissolved minerals. In this way, weathered rinds can form (Auler \& Smart 2004).

Physically based models of the growth of depositional forms within caves have also been developed. Stalactite shape was modeled, and a simple general shape that fits many real stalactites was found (Short et al. 2005). Shapes of stalagmites forming in either steadystate or variable conditions were explained through numerical modeling as well (Romanov et al. 2008). The development of crenulations on speleothems was studied through a stability analysis that demonstrated that the migration pattern of these forms within a speleothem is correlated to film flow rates (Camporeale \& Ridolfi 2012). Speleothems are useful for reconstructing paleoclimate (Harmon et al. 1978; Baker et al. 1993), and numerical models of their formation are being used in this context (Mariethoz et al. 2012).

Relatively few physics-based models have been developed for karst surface processes or for processes in the epikarst and vadose zone. Gabrovšek (2007) developed a simple model for the vertical distribution of dissolution in a karst aquifer. Using the characteristic length scale for dissolution in vertical fractures, Gabrovšek (2007) examined the assumptions behind the maximum denudation models that use recharge and equilibrium calcium concentrations to estimate denudation rates in a karst terrain. He finds that the maximum denudation formulation is reasonable in most cases, even though not all dissolution occurs at the surface. A number of studies have shown that $\mathrm{CO}_{2}$ concentrations can increase substantially with depth in the vadose zone (e.g. Atkinson 1977; Wood 1985), and recent work suggests that high levels of $\mathrm{CO}_{2}$ may be primarily responsible for dissolution in eogenetic karst settings rather than mixing corrosion (Gulley et al. 2014, 2015). Additionally, Covington (in press) uses dimensional analysis of models of $\mathrm{CO}_{2}$ transport in the vadose zone to suggest that advection of both air and water are important processes in determining the spatial and temporal distributions of $\mathrm{CO}_{2}$. Vertical changes in the partial pressure of $\mathrm{CO}_{2}$ within karst systems have not typically been considered in karst evolution models, and these may be important in determining the distribution of dissolution rates throughout the system.

\section{CONCLUSIONS}

Scientific research often benefits from the interaction between disparate fields. There is a long and continuing history of physicists working within the field of cave and karst science. We argue that this work has provided a substantial contribution to the field, largely as a result of a difference in approach. The physicist is driven to find general mathematical descriptions for the behavior of a system. When dealing with complex systems, a common approach within physics is to develop relatively simple models, sometimes called "toy models," that capture the essence of the dynamics. When successful, this approach provides a powerful tool for understanding and gener- alization. It can aid in the interpretation of numerical simulations, experiments, and observational data. Simple models have been and continue to be applied to processes within karst. They have provided a general framework for understanding a variety of phenomena, from cave climate and meteorology, to karst transport, to speleogenesis. This work is hardly done, and there are many open questions that we have attempted to elucidate above. In our judgement, many of the most exciting potential advances relate to the interactions between these three sets of processes.

\section{ACKNOWLEDGMENTS}

We thank Wolfgang Dreybrodt, whose headlamp has shown the way, and Franci Gabrovšek and Lee Florea for helpful reviews that substantially improved this work. We also acknowledge inspiration for the title from John Harte's book "Consider a Spherical Cow" (Harte 1998). M.D.C. and M.P. acknowledge support from the National
Science Foundation under grant no. 1226903, M.P. acknowledges support of the Slovenian Research Agency through Research Programme P2-0001. The data displayed in Fig. 2 were collected by students in M.D.C.'s fall 2014 Karst Hydrogeology course. 


\section{REFERENCES}

Andre, B.J. \& H. Rajaram, 2005: Dissolution of limestone fractures by cooling waters: Early development of hypogene karst systems.- Water Resources Research, 41, 1-16.

Ashton, K., 1966: The analysis of flow data from karst drainage systems.- Transactions of the Cave Research Group of Great Britain, 7, 2, 163-203.

Atkinson, T., 1977: Carbon dioxide in the atmosphere of the unsaturated zone: An important control of groundwater hardness in limestones.- Journal of Hydrology, 35, 1-2, 111-123.

Audra, P., Bigot, J.Y. \& L. Mocochain, 2002: Hypogenic caves in Provence (France): Specific features and sediments.- Acta Carsologica, 31, 3, 33-50.

Audra, P., Mocochain, L., Bigot, J.Y. \& J.C. Nobecourt, 2009: Hypogene cave patterns. In: Hypogene Speleogenesis and Karst Hydrogeology of Artesian Basins. Special Paper, 1, Ukrainian Institute of Speleology and Karstology.

Auler, A.S. \& P.L. Smart, 2004: Rates of condensation corrosion in speleothems.- Speleogenesis and evolution of karst aquifers, 2, 2.

Badino, G., 1995: Fisica del Clima Sotterraneo-Memorie IIS.- Volume 7. Istituto Italiano di Speleologia, Bologna, Italy.

Badino, G., 2004: Cave temperatures and global climate change.- International Journal of Speleology, 33, 1, 103-114.

Badino, G., 2005: Underground drainage systems and geothermal flux.- Acta Carsologica, 34, 2, 277-316.

Badino, G., 2010: Underground meteorology -What's the weather underground? Podzemna meteorologija: Kakšno je vreme v podzemlju?.- Acta Carsologica, 39, 3, 427-448.

Baker, A., Smart, P.L., Edwards, R.L. \& D.A. Richards, 1993: Annual growth banding in a cave stalagmite.Nature, 364, 518-520.

Baldini, J.U.L., 2010: Cave atmosphere controls on stalagmite growth rate and palaeoclimate records.Geological Society, London, Special Publications, 336, 283-294.

Banner, J.L., Guilfoyle, A., James, E.W., Stern, L.A. \& M. Musgrove, 2007: Seasonal Variations in Modern Speleothem Calcite Growth in Central Texas, U.S.A..- Journal of Sedimentary Research, 77, 1994, 615-622.

Bauer, S., Liedl, R. \& M. Sauter, 2003: Modeling of karst aquifer genesis: Influence of exchange flow.- Water Resources Research, 39, 10, 1-12.
Benderitter, Y., Roy, B. \& A. Tabbagh, 1993: Flow characterization through heat transfer evidence in a carbonate fractured medium: first approach.- Water resources research, 29, 11, 3741-3747.

Birk, S., Liedl, R. \& M. Sauter, 2006: Karst spring responses examined by process-based modeling.Groundwater, 44, 6, 832-836.

Birk, S., Liedl, R., Sauter, M. \& G. Teutsch, 2005: Simulation of the development of gypsum maze caves.Environmental Geology, 48, 3, 296-306.

Blumberg, P. \& R.L. Curl, 1974: Experimental and theoretical studies of dissolution roughness.Journal of Fluid Mechanics, 65, 4, 735-751.

Bogli, A., 1980: Karst Hydrology and Physical Speleology.- Springer-Verlag.

Breecker, D.O., Payne, A.E., Quade, J., Banner, J.L., Ball, C.E., Meyer, K.W. \& B.D. Cowan, 2012: The sources and sinks of $\mathrm{CO} 2$ in caves under mixed woodland and grassland vegetation.- Geochimica et Cosmochimica Acta, 96, 230-246.

Buecher, R.H., 1999: Microclimate study of Kartchner Caverns, Arizona.- Journal of Cave and Karst Studies, 61, 108-120.

Buhmann, D. \& W. Dreybrodt, 1985a: The kinetics of calcite dissolution and precipitation in geologically relevant situations of karst areas: 1. Open system.Chemical Geology, 48, 1-4, 189-211.

Buhmann, D. \& W. Dreybrodt, 1985b: The kinetics of calcite dissolution and precipitation in geologically relevant situations of karst areas: 2 . Closed system.Chemical Geology, 53, 1-2, 109-124.

Camporeale, C. \& L. Ridolfi, 2012: Hydrodynamicdriven stability analysis of morphological patterns on stalactites and implications for cave paleoflow reconstructions.- Physical review letters, 108, 23, 238501.

Chatanantavet, P. \& G. Parker, 2009: Physically based modeling of bedrock incision by abrasion, plucking, and macroabrasion.- Journal of Geophysical Research, 114, F4, 1-22.

Chaudhuri, A., Rajaram, H. \& H. Viswanathan, 2008: Alteration of fractures by precipitation and dissolution in gradient reaction environments: Computational results and stochastic analysis.- Water Resources Research, 44, 10, 1-19.

Chaudhuri, A., Rajaram, H. \& H. Viswanathan, 2013: Early-stage hypogene karstification in a mountain hydrologic system: A coupled thermohydrochemical model incorporating buoyant convection.- Water Resources Research, 49, 9, 5880-5899. 
Chaudhuri, A., Rajaram, H., Viswanathan, H., Zyvoloski, G. \& P. Stauffer, 2009: Buoyant convection resulting from dissolution and permeability growth in vertical limestone fractures.Geophysical Research Letters, 36, 3 .

Cigna, A.A., 1968: An analytical study of air circulation in caves.- International Journal of Speleology, 3, 1, 41-54.

Cigna, A.A., 1993: Environmental management of tourist caves.- Environmental Geology, 21, 3, 173-180.

Cooper, M., Perne, M. \& M. Covington, 2014: Simple shear stress approximations and a first step in modeling mechanical erosion in caves.- GSA Abstracts with Programs, 46, 534.

Covington, M., 2014: Calcite dissolution under turbulent flow conditions: a remaining conundrum.- Acta Carsologica, 43, 195-202.

Covington, M., in press: The importance of advection for $\mathrm{CO} 2$ dynamics in the karst Critical Zone: an approach from dimensional analysis.- Geological Society of America Special Papers: Caves and Karst Across Time, 516.

Covington, M., Gulley, J. \& F. Gabrovšek, 2015: Natural variations in calcite dissolution rates in streams: Controls, implications, and open questions.- Geophysical Research Letters, 42, 8, 2836-2843.

Covington, M.D., Banwell, A., Gulley, J.D., Saar, M., Willis, I. \& C. Wicks, 2012a: Quantifying the effects of glacier conduit geometry and recharge on proglacial hydrograph form.- Journal of Hydrology, 414415, 59-71.

Covington, M.D., Luhmann, A.J., Gabrovšek, F., Saar, M.O. \& C.M. Wicks, 2011: Mechanisms of heat exchange between water and rock in karst conduits.Water Resources Research, 47, 10, W10514.

Covington, M.D., Luhmann, A.J., Wicks, C.M. \& M.O. Saar, 2012b: Process length scales and longitudinal damping in karst conduits.- Journal of Geophysical Research, 117, F1, 1-19.

Covington, M.D., Prelovšek, M. \& F. Gabrovšek, 2013: Influence of $\mathrm{CO}_{2}$ dynamics on the longitudinal variation of incision rates in soluble bedrock channels: Feedback mechanisms.Geomorphology, 186, 85-95.

Covington, M.D., Wicks, C.M. \& M.O. Saar, 2009: A dimensionless number describing the effects of recharge and geometry on discharge from simple karstic aquifers.- Water Resources Research, 45, 11, W11410.

Culver, D., 2005: Ecotones.-In: D. Culver \& W. White (eds.), Encyclopedia of caves, Elsevier, pp. 206-208.

Curl, R.L., 1966: Cave conduit enlargement by natural convection.- Cave Notes, $8,1,4-8$.
Dietrich, W.E., Bellugi, D.G., Sklar, L.S., Stock, J.D., Heimsath, A.M. \& J.J. Roering, 2003: Geomorphic Transport Laws for Predicting Landscape Form and Dynamics.- Geophysical Monograph, 135, 1-30.

Domenico, P. \& V. Palciauskas, 1973: Theoretical analysis of forced convective heat transfer in regional ground-water flow.- Bulletin of the Geological Society of America, 84, 12, 3803-3814.

Dreiss, S., 1982: Linear kernels for karst aquifers.- Water Resources Research, 18, 4, 865-876.

Dreybrodt, W., 1988: Processes in Karst Systems: Physics, Chemistry, and Geology.- Springer, pp. 288, New York, USA.

Dreybrodt, W., 1996: Principles of early development of karst conduits under natural and man-made conditions revealed by mathematical analysis of numerical models.- Water Resources Research, 32, 9, 2923.

Dreybrodt, W. \& D. Buhmann, 1991: A mass transfer model for dissolution and precipitation of calcite from solutions in turbulent motion.- Chemical Geology, 90, 1-2, 107-122.

Dreybrodt, W. \& F. Gabrovšek, 2000: Dynamics of the evolution of single karst conduits.- In: Speleogenesis: Evolution of karst aquifers, pp. 184-193.

Dreybrodt, W., Gabrov`sek, F. \& D. Romanov, 2005a: Processes of Speleogenesis: A Modeling Approach.ZRC Publishing, pp. 376, Ljubljana, Slovenia.

Dreybrodt, W., Gabrovšek, F. \& M. Perne, 2005b: Condensation corrosion: a theoretical approach.- Acta Carsologica, 32, 2, 317-348.

Dreybrodt, W. \& D. Romanov, 2007: Time scales in the evolution of solution porosity in porous coastal carbonate aquifers by mixing corrosion in the saltwater-freshwater transition zone.In: Time in Karst, Postojna, pp. 25-34.

Dreybrodt, W., Romanov, D. \& F. Gabrovšek, 2002: Karstification below dam sites: a model of increasing leakage from reservoirs.- Environmental Geology, 42, 5, 518-524.

Dreybrodt, W., Romanov, D. \& G. Kaufmann, 2009: Evolution of isolated caves in porous limestone by mixing of phreatic water and surface water at the water table of unconfined aquifers: A model approach.Journal of Hydrology, 376, 1-2, 200-208.

Dublyansky, V.N. \& Y.V. Dublyansky, 2000: The role of condensation in karst hydrogeology and speleogenesis.- In: A. Klimchouk, D.C. Ford, A. Palmer \& W. Dreybrodt (eds.), Speleogenesis: Evolution of karst aquifers. National Speleological Society, pp. 100111, Huntsville, pp. 100-111. 
Eisenlohr, L., Kir'aly, L., Bouzelboudjen, M. \& Y. Rossier, 1997: Numerical simulation as a tool for checking the interpretation of karst spring hydrographs.Journal of Hydrology, 193, 1-4, 306-315.

Emmanuel, S. \& Y. Levenson, 2014: Limestone weathering rates accelerated by micron-scale grain detachment.- Geology, 42, 9, 751-754.

Fairchild, I.J., Smith, C.L., Baker, A., Fuller, L., Spotl, C., Mattey, D., McDermott, F. \& E. I. M. F., 2006: Modification and preservation of environmental signals in speleothems. Earth Science Reviews, 75, 105-153.

Farrant, A.R. \& P.L. Smart, 2011: Role of sediment in speleogenesis; sedimentation and paragenesis.Geomorphology, 134, 79-93.

Finnegan, N.J., Roe, G., Montgomery, D.R. \& B. Hallet, 2005: Controls on the channel width of rivers: Implications for modeling fluvial incision of bedrock.Geology, 33, 3, 229.

Gabrovšek, F., 2007: On denudation rates in karst: O hitrosti denudacije na Krasu.- In: Time in Karst, Postojna, pp. 7-13.

Gabrovšek, F. \& W. Dreybrodt, 2000: Role of mixing corrosion in calcite-aggressive $\mathrm{H}_{2} \mathrm{OCO}_{2}-\mathrm{CaCO}_{3}$ solutions in the early evolution of karst aquifers in limestone.- Water Resources Research, 36, 5, 1179 1188.

Gabrovšek, F. \& W. Dreybrodt, 2001: A model of the early evolution of karst aquifers in limestone in the dimensions of length and depth.- Journal of Hydrology, 240, 3-4, 206-224.

Gabrovšek, F., H“auselmann, P. \& P. Audra, 2014: Looping caves versus water table caves: The role of baselevel changes and recharge variations in cave development.- Geomorphology, 204, 683-691.

Gabrovšek, F., Menne, B. \& W. Dreybrodt, 2000: A model of early evolution of karst conduits affected by subterranean $\mathrm{CO}_{2}$ sources.- Environmental Geology, $39,6,531-543$.

Gabrovšek, F., Romanov, D. \& W. Dreybrodt, 2004: Early karstification in a dual-fracture aquifer: The role of exchange flow between prominent fractures and a dense net of fissures.- Journal of Hydrology, 299, 45-66.

Geyer, T., Birk, S., Liedl, R. \& M. Sauter, 2008: Quantification of temporal distribution of recharge in karst systems from spring hydrographs.- Journal of Hydrology, 348, 3-4, 452-463.

Grasso, D. \& P.Y. Jeannin, 2002: A Global Experimental System Approach of Karst Springs' Hydrographs and Chemographs.- Ground Water, 40, 6, 608-618.
Groves, C.G. \& A.D. Howard, 1994: Minimum hydrochemical conditions allowing limestone cave development.- Water Resources Research, 30, 3, 607615.

Gulley, J., Martin, J. \& P. Moore, 2014: Vadose CO2 gas drives dissolution at water tables in eo-genetic karst aquifers more than mixing dissolution.- Earth Surface Processes and Landforms, 39, 13, 1833-1846.

Gulley, J.D., Martin, J.B., Moore, P.J., Brown, A., Spellman, P.D. \& J. Ezell, 2015: Heterogeneous distributions of $\mathrm{CO} 2$ may be more important for dissolution and karstification in coastal eogenetic limestone than mixing dissolution.- Earth Surface Processes and Landforms, 40, 1057-1071.

Gulley, J.D., Martin, J.B., Moore, P.J. \& J. Murphy, 2013: Formation of phreatic caves in an eogenetic karst aquifer by $\mathrm{CO} 2$ enrichment at lower water tables and subsequent flooding by sea level rise.- Earth Surface Processes and Landforms, 38, 1210-1224.

Halihan, T. \& C.M. Wicks, 1998: Modeling of storm responses in conduit flow aquifers with reservoirs.Journal of Hydrology, 208, 1-2, 82-91.

Hammer, Ø., Lauritzen, S.E. \& B. Jamtveit, 2011: Stability of dissolution flutes under turbulent flow.- Journal of Cave and Karst Studies, 73, 3, 181-186.

Hanna, R. \& H. Rajaram, 1998: Influence of aperture variability on dissolutional growth of fissures in karst formations.- Water Resources Research, 34, 11, 2843-2853.

Harmon, R.S., Schwarcz, H.P. \& D.C. Ford, 1978: Late pleistocene sea level history of bermuda.Quaternary Research, 9, 2, 205 - 218.

Harte, J., 1998: Consider a Spherical Cow.-University Science Books, pp. 283, Sausalito, CA, USA.

Heller, E.J. \& S. Tomsovic, 1993: Postmodern quantum mechanics.- Physics Today, 46, 38-46.

Hoyos, M., Ca naveras, J.C., S'anchez-Moral, S., SanzRubio, E. \& V. Soler, 1998: Microclimatic characterization of a karstic cave: Human impact on microenvironmental parameters of a prehistoric rock art cave (Candamo Cave, northern Spain).- Environmental Geology, 33, March, 231-242.

James, E.W., Banner, J.L. \& B. Hardt, 2015: A global model for cave ventilation and seasonal bias in speleothem paleoclimate records.- Geochemistry, Geophysics, Geosystems, 16, 1044-1051.

Jeannin, P.Y. \& M. Sauter, 1998: Analysis of karst hydrodynamic behaviour using global approach: a review.- Bulletin d' Hydrogéologie, 16, 31-48.

Kaufmann, G., 2009: Modelling karst geomorphology on different time scales.- Geomorphology, 106, 1-2, 62-77. 
Kaufmann, G. \& J. Braun, 2000: Karst aquifer evolution in fractured, porous rocks.- Water Resources Research, 36, 6, 1381-1391.

Klimchouk, A., 2007: Hypogene speleogenesis: hydrogeological and morphogenetic perspective. Special Paper 1.- National Cave and Karst Research Institute.

Kovacs, A., Perrochet, P., Kiraly, L. \& P.Y. Jeannin, 2005: A quantitative method for the characterisation of karst aquifers based on spring hydrograph analysis.- Journal of Hydrology, 303, 1-4, 152-164.

Labat, D., Ababou, R. \& A. Mangin, 2000: Rainfall-runoff relations for karstic springs. Part I: convolution and spectral analyses.- Journal of Hydrology, 238, 3-4, $123-148$.

Lamb, M.P., Dietrich, W.E. \& L.S. Sklar, 2008: A model for fluvial bedrock incision by impacting suspended and bed load sediment.- Journal of Geophysical Research, 113, F3, 1-18.

Lauritzen, S. \& J. Lundberg, 2000: Meso-and micromorphology of caves: solutional and erosional morphology.-In: A. Klimchouk, D. Ford, A. Palmer \& W. Dreybrodt (eds.), Speleogenesis: evolution of karst aquifers, National Speleological Society, pp. 408-426.

Liedl, R. \& M. Sauter, 1998: Modelling of aquifer genesis and heat transport in karst systems.Bulletin $\mathrm{d} \mathrm{Hy-}$ drogéologie, 16, 185-200.

Liedl, R., Sauter, M., Hückinghaus, D., Clemens, T. \& G. Teutsch, 2003: Simulation of the development of karst aquifers using a coupled continuum pipe flow model.- Water Resources Research, 39, 3, 1-11.

Lismonde, B., 2002: Climatologie du Monde Souterrain: Aérologie des systèmes karstiques. Comité Départemental de Spéléologie de l'Isére, pp. 362, Grenoble, France.

Long, A.J. \& P.C. Gilcrease, 2009: A one-dimensional heat-transport model for conduit flow in karst aquifers.- Journal of Hydrology, 378, 3-4, 230-239.

Luetscher, M. \& P.Y. Jeannin, 2004: Temperature distribution in karst systems: the role of air and water fluxes.- Terra Nova, 16, 6, 344-350.

Luetscher, M., Lismonde, B. \& P.Y. Jeannin, 2008: Heat exchanges in the heterothermic zone of a karst system: Monlesi cave, Swiss Jura Mountains.- Journal of Geophysical Research, 113, F2, F02025.

Luhmann, A.J., Covington, M.D., Alexander, S.C., Chai, S.Y., Schwartz, B.F., Groten, J.T. \& E.C. Alexander, 2012: Comparing conservative and nonconservative tracers in karst and using them to estimate flow path geometry.- Journal of Hydrology, 448-449, 201-211.
Luhmann, A.J., Covington, M.D., Myre, J.M., Perne, M., Jones, S.W., Alexander Jr., E.C. \&

M.O. Saar, 2015: Thermal damping and retardation in karst conduits.- Hydrology and Earth System Sciences, 19, 1, 137-157.

Lučić, I., 2011: Interview with Wolfgang Dreybrodt.Acta Carsologica, 40, 225-232.

Maillet, E., 1905: Essais d'hydraulique souterraine et fluviale.- Paris.

Mariethoz, G., Kelly, B.F.J. \& A. Baker, 2012: Quantifying the value of laminated stalagmites for paleoclimate reconstructions.- Geophysical Research Letters, 39, 5.

Milanolo, S. \& F. Gabrovšek, 2009: Analysis of Carbon Dioxide Variations in the Atmosphere of Srednja Bijambarska Cave, Bosnia and Herzegovina.Boundary-Layer Meteorology, 131, 3, 479-493.

Montgomery, D.R. \& K.B. Gran, 2001: Downstream variations in the width of bedrock channels.- Water Resources Research, 37, 6, 1841-1846.

Mylroie, J.E., 2008: Review of the book Hypogene Speleogenesis: Hydrogeological and Morphogenetic Perspective.- Journal of Cave and Karst Studies, 70, 129-131.

Newson, M., 1971: A model of subterranean limestone erosion in the British Isles based on hydrology.Transactions of the Institute of British Geographers, 54, 55-70.

Opdyke, B.N., Gust, G. \& J.R. Ledwell, 1987: Mass transfer from smooth alabaster surfaces in turbulent flows.- Geophysical Research Letters, 14, 11, 11311134.

Padilla, A. \& A. Pulido-Bosch, 1995: Study of hydrographs of karstic aquifers by means of correlation and cross-spectral analysis.- Journal of Hydrology, $168,73-89$.

Palmer, A.N., 1991: Origin and morphology of limestone caves.- Bulletin of the Geological Society of America, $103,1,1$.

Palmer, A.N., 2011: Distinction between epigenic and hypogenic maze caves.- Geomorphology, 134, 1-2, 9-22.

Perne, M., 2012: Modelling speleogenesis in transition from pressurised to free surface flow.Ph.D. thesis, University of Nova Gorica.

Perne, M., Covington, M. \& M. Cooper, 2014a: Bedrock channel and cave evolution models based on computational fluid dynamics.- Fall Meeting, AGU, San Francisco, CA, 3-7 Dec.

Perne, M., Covington, M.D. \& F. Gabrovšek, 2014b: Evolution of karst conduit networks in transition from pressurized flow to free-surface flow.- Hydrology and Earth System Sciences, 18, 4617-4633. 
Plummer, L., Wigley, T. \& D.L. Parkhurst, 1978: The Kinetics of Calcite Dissolution in $\mathrm{CO}_{2}$ Water Systems at $5^{\circ}$ to $60{ }^{\circ} \mathrm{C}$ and 0.0 to 1.0 ATM $\mathrm{CO}_{2}$.- American $^{-}$ Journal of Science, 278, 179-216.

Reimann, T., Geyer, T., Shoemaker, W.B., Liedl, R. \& M. Sauter, 2011: Effects of dynamically variable saturation and matrix-conduit coupling of flow in karst aquifers.- Water Resources Research, 47, 1-19.

Romanov, D., Kaufmann, G. \& W. Dreybrodt, 2008: Modeling stalagmite growth by first principles of chemistry and physics of calcite precipitation.- Geochimica et Cosmochimica Acta, 72, 2, 423 - 437.

Sanchez-Canete, E.P., Serrano-Ortiz, P., Domingo Poveda, F. \& A.S. Kowalski, 2013: Cave ventilation is influenced by variations in the $\mathrm{CO}_{2}$-dependent virtual temperature.- International Journal of Speleology, 42, 1-8.

Sarbu, S.M. \& C. Lascu, 1997: Condensation corrosion in Movila cave, Romania.- Journal of Cave and Karst Studies, 59, 3, 99-102.

Serrano-Ortiz, P., Roland, M., Sanchez-Moral, S., Janssens, I.A., Domingo, F., Goddéris, Y. \& A. Kowalski, 2010: Hidden, abiotic $\mathrm{CO}_{2}$ flows and gaseous reservoirs in the terrestrial carbon cycle: review and perspectives.- Agricultural and Forest Meteorology, 150, 321-329.

Short, M.B., Baygents, J.C., Beck, J.W., Stone, D.A., Toomey, R.S. \& R.E. Goldstein, 2005: Stalactite growth as a free-boundary problem: A geometric law and its platonic ideal.- Phys. Rev. Lett., 94, 018501.

Siemers, J. \& W. Dreybrodt, 1998: Early development of karst aquifers on percolation networks of fractures in limestone.- Water Resources Research, 34, 3, 409-419.

Sklar, L.S. \& W.E. Dietrich, 2004: A mechanistic model for river incision into bedrock by saltating bed load.- Water Resources Research, 40, 6, 1-22.

Spötl, C., Fairchild, I.J. \& A.F. Tooth, 2005: Cave air control on dripwater geochemistry, Obir Caves (Austria): Implications for speleothem deposition in dynamically ventilated caves.- Geochimica et Cosmochimica Acta, 69, 10, 2451-2468.

Stafford, K., Land, L. \& G. Veni (eds.), 2009: Advances in hypogene karst studies. Symposium 1.- National Cave and Karst Research Institute.
Szymczak, P. \& A.J. Ladd, 2011: The initial stages of cave formation: beyond the one-dimensional paradigm.Earth and Planetary Science Letters, 301, 3-4, 424432.

Szymczak, P. \& A.J.C. Ladd, 2012: Reactive-infiltration instabilities in rocks: fracture dissolution.- Journal of Fluid Mechanics, 702, 239-264.

Tarhule-Lips, R.F.A. \& D.C. Ford, 1998: Condensation corrosion in caves on Cayman Brac and Isla de Mona.- Journal of Cave and Karst Studies, 60, 2, 84-95.

Tobin, B.W., Hutchins, B.T. \& B.F. Schwartz, 2013: Spatial and temporal changes in invertebrate assemblage structure from the entrance to deep-cave zone of a temperate marble cave.International Journal of Speleology, 42, September, 203-214.

Weisbrod, N., Dragila, M., Nachshon, U. \& M. Pillersdorf, 2009: Falling through the cracks: The role of fractures in Earth-atmosphere gas exchange.- Geophysical Research Letters, 36, L02401.

Whipple, K.X., Hancock, G.S. \& R.S. Anderson, 2000: River incision into bedrock: Mechanics and relative efficacy of plucking, abrasion, and cavitation.Geological Society of America Bulletin, 112, 3, 490-503.

Wigley, T. \& M. Brown, 1976: The Physics of Caves.-In: T. Ford \& C. Cullingford (eds.), The Science of Speleology. Academic Press, pp. 329-358, New York, pp. 329-358.

Wigley, T.M.L. \& M. Brown, 1971: Geophysical applications of heat and mass transfer in turbulent pipe flow.- Boundary-Layer Meteorology, 1, 1968, 300320.

Wigner, E., 1960: The unreasonable effectiveness of mathematics in the natural sciences.- Communications on Pure and Applied Mathematics, 13, 1-14.

Wood, W.W., 1985: Origin of caves and other solution openings in the unsaturated (vadose) zone of carbonate rocks: A model for $\mathrm{CO}_{2}$ generation.- Geology, 13, 822-824.

Yanites, B.J. \& G.E. Tucker, 2010: Controls and limits on bedrock channel geometry.- Journal of Geophysical Research, 115, F04019, 1-17. 